\title{
Western Ragweed Pollen IgA Measurement
}

National Cancer Institute

\section{Source}

National Cancer Institute. Western Ragweed Pollen IgA Measurement. NCI Thesaurus.

Code 1130093.

A measurement of the western ragweed (Ambrosia psilostachya) pollen IgA in a biological specimen. 